\title{
I STUDENTĄ SUTELKTOS STUDIJOS KAIP KARJEROS KŪRIMO PRIELAIDA
}

\author{
Doc. dr. Jūratė Guščinskienė \\ Generolo Jono Žemaičio Lietuvos karo akademija \\ Prof. dr. Jadvyga Čiburienė
}

Kauno technologijos universitetas

\begin{abstract}
Anotacija. Straipsnyje aptariamos ị studentą sutelktos studijos aukštojoje mokykloje ir principai, kuriais remiantis vyksta mokymas(is), apibüdinamas studento ir dèstytojo santykiu pokytis, parodoma šiu studiju nauda asmeniui ir visuomenei. XXI a. karjera suprantama kaip procesas, vykstantis dinamiškoje darbo rinkoje, todèl jos sèkmè priklauso nuo kiekvieno individo gebejimo laiku ir tinkamai reaguoti i pokyčius, juos prognozuoti, jiems pasirengti ir priimti tinkamus sprendimus. Pabrèžiama, kad karjera - tai visa gyvenima trunkanti asmens darbo ir mokymosi patirčiu seka, kuriai nemaža ịtaka daro studiju, sutelktu i studenta, metu igytos žinios, gebejjimai, igūdžiai ir kompetencijos. Karjeros kūrimas suprantamas kaip jos planavimas ir projektavimas. Straipsnyje pateikti karjeros kūrimo pavyzdžiai iš Lietuvos ir užsienio aukštuju mokyklu praktikos.
\end{abstract}

Pagrindiniai žodžiai: $i$ studenta sutelktos studijos, aukštoji mokykla, karjera, karjeros planavimas ir projektavimas, karjeros kūrimas.

\section{Ivadas}

Pasauliniu lygiu besiplečiantys globalizacijos, ekonominės integracijos procesai vyksta žinių visuomenès kūrimo, grindžiamo karjera, pagrindu. Karjera suprantama kaip asmens darbinès veiklos konkrečioje srityje, profesijoje kitimas laiko požiūriu. Šiandieninèje visuomenèje karjera apibūdina sėkmingą individo veiklą ir gyvenimą. Vakarų pasaulyje karjeros sampratos raidą galima suskirstyti i kelis etapus: 1) XX a. pirmojoje pusèje vyravo profesinio orientavimo samprata; 2) $\mathrm{XX}$ a. antrojoje pusèje (iki 9 dešimtmečio pab.) - biurokratinè arba tradicinè karjeros samprata; 3) XX a. pabaigoje (nuo 9 dešimtmečio pab.) - individuali karjeros samprata. XXI a. karjera suprantama kaip procesas, realizuojamas dinamiškoje darbo rinkoje, todèl jos sėkmè priklauso nuo kiekvieno individo gebejjimo laiku ir tinkamai reaguoti i pokyčius, juos prognozuoti, jiems pasirengti ir priimti tinkamus sprendimus. Karjera kuriama sąveikaujant individui, organizacijai ir visuomenei, t. 
y. ji planuojama ir projektuojama derinant formalujị ir neformalųji ugdymą, plètojant socialinius tinklus ir kt.

Ypač svarbus vaidmuo šiame karjeros projektavimo procese tenka aukštajai mokyklai, nes aukštojo mokslo plètra yra viena iš visuomenès vystymosi sąlygų. Ryšys tarp aukštojo mokslo sistemos ir darbo rinkos užtikrinamas per studentų igytas žinias, gebejjimus, kompetencijas ir įgūdžius. İ studentą sutelktas mokymas(is) remiasi keliais principais, $\mathfrak{i}$ kuriuos būtina atsižvelgti: studentų mokymosi stilius, poreikiai ir lūkesčiai skiriasi; nèra vienintelio teisingo mokymo(si) metodo; studentams sudaromos galimybès rinktis, ir tai skatina jų atsakingumą ir suinteresuotumą; dèstytojo darbas tampa orientuotas ne į nurodymą, bet ị igalinimą; aktyvusis mokymasis keičia pasyvuji mokymą; paviršutinišką informacijos įsisavinimą keičia nuodugnus jos suvokimas; ugdoma studento ir dèstytojo abipuse pagarba; suaktyvejja studentų ir dèstytojų bendradarbiavimas - dialogas tampa studijų esme; mokymo(si) procesas yra nuolat stebimas, kontroliuojamas ir vertinamas.

Tyrimo problema -ị studentą sutelktos studijos kaip karjeros kūrimo prielaida.

Tyrimo objektas - i studentą sutelktos studijos.

Tyrimo tikslas - išanalizuoti ị studentą sutelktas studijas kaip karjeros kūrimo prielaidą.

\section{Tyrimo uždaviniai:}

1) ištirti ị studentą sutelktas studijas;

2) išanalizuoti karjeros sampratą ir jos kūrimo prielaidas aukštojoje mokykloje.

Tyrimo metodai-mokslinès literatūros ir dokumentų analizè, interpretacija.

\section{I studentą sutelktos studijos}

XX a. pr. įvyko nemažai pokyčių, kai buvo atkreiptas dėmesys į studento (besimokančiojo) vaidmenị mokymo(si) procese. Taip gimė „nauja“ paradigma - i studentą sutelktos studijos, kurių raidą, pasak Sajienès ir Tamulienès (Sajienė, Tamulienè, 2012, p. 97-98), galima suskirstyti ị du etapus:1) laikotarpị iki Bolonijos proceso, kuriam būdinga orientacija ị besimokantị individą, pabrèžiant jo poreikius ir interesų ratą, ir 2) Bolonijos proceso laikotarpi (Londono komunikatas, 2007; Liuveno komunikatas, 2009; Budapešto-Vienos komunikatas, 2010), kuriam būdinga orientacija į visuomenę ir jos gerovę, akcentuojami besimokančiujų studijų rezultatai, nuo kurių priklauso šalies ekonomikos raida.

Studentai, desstytojai ir administracija - tai trys tarpusavyje susiję subjektai, dalyvaujantys studijų procese. İ studentą sutelktas mokymas(is) remiasi keliais principais:

1) studentas pats atsakingas už savo mokymąsi, jis aktyviai dalyvauja tobulindamas ir keisdamas save;

2) mokant(is) reikia nuolat reflektuoti; 
3) nesilaikoma vieno visiems tinkamo mokymo metodo, todèl besimokantieji mokosi skirtingai;

4) studentai turi individualius ir neretai skirtingus poreikius ir interesus;

5) studijų procese atsiranda pasirinkimo galimybė;

6) taikomi aktyvūs mokymo metodai;

7) orientuojamasi į skirtingas studentų žinias;

8) besimokantieji turi patys kontroliuoti savo mokymąsi;

9) studentų igalinimas mokymosi procese (ne tik žinių (informacijos) atkartojimas);

10) studento ir déstytojo, studento ir administracijos bendradarbiavimas.

Šiandieninėje darbo rinkoje ypatingas dėmesys skiriamas darbuotojų igytoms kompetencijoms. Todèl neatsitiktinai darniai funkcionuojant visiems ị studentą sutelkto mokymo(si) pokyčiu modelio elementams, kaip pavaizduota 1 pav., sèkmingiau ugdomos šios besimokančiujų aukštojoje mokykloje kompetencijos: profesinè, socialinè, bendrakultūrinè, efektyvios veiklos, komunikacinè, informacijos ir pokyčių valdymo.

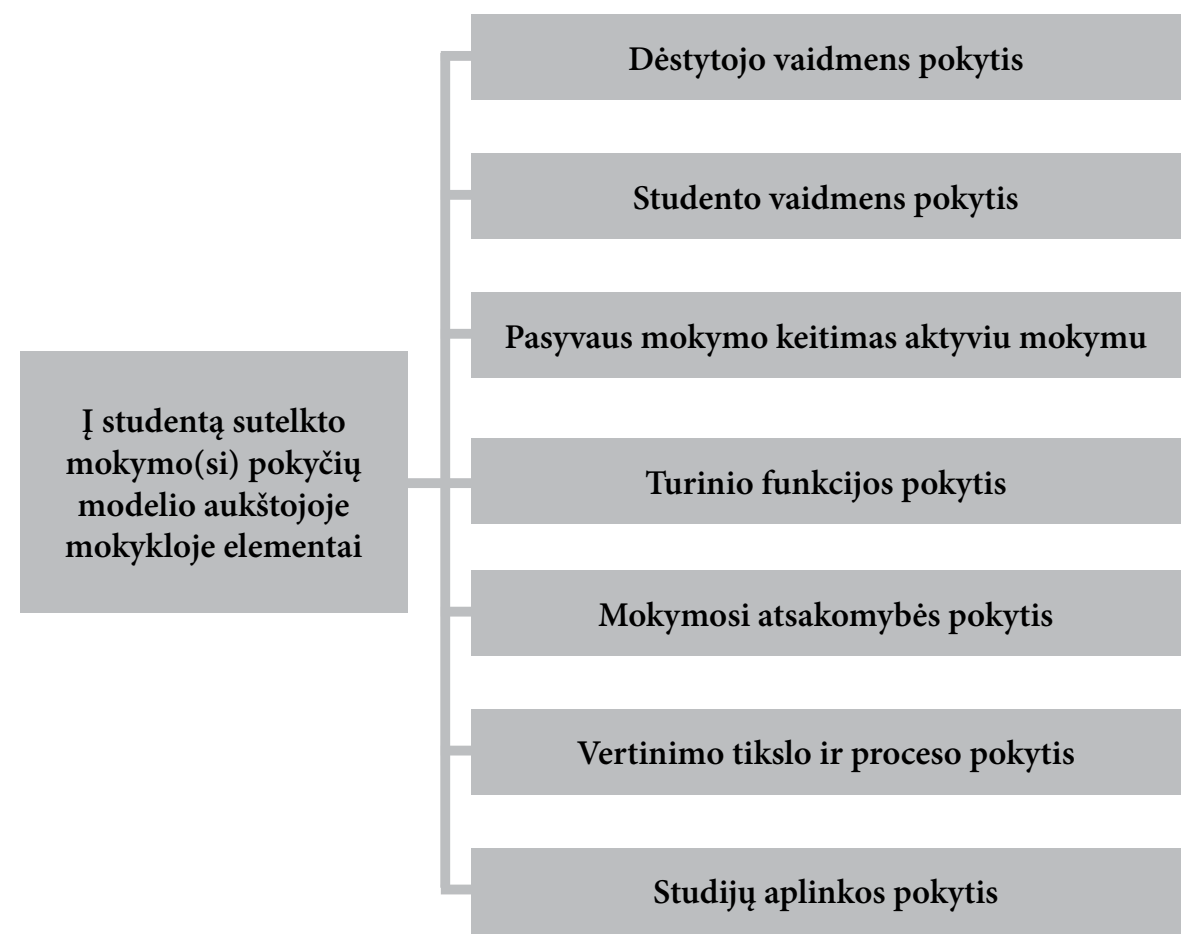

1 pav. I studentą sutelkto mokymo(si) pokyčių modelio aukštojoje mokykloje elementai Šaltiniai: sudaryta pagal Weimer, 2013, p. 57-168; Cox, 2011; Peilakauskaitè ir kt., 2011, p. 12-17; Sajienè, Tamulienè, 2012; Powell, 2014 
Studijuojant išugdytomis kompetencijomis asmens igytos teorinès žinios susiejamos su praktiniais ịgūdžiais ir derinamos su rinkos poreikiais, ugdomas gebèjimas bendrauti ir spręsti iškilusias problemas, vystomas gebejjimas priimti, perduoti ir interpretuoti informaciją, ugdoma orientacija ị užsibrèžtą tikslą ir absolventas igalinamas įžvelgti, taip pat sėkmingai diegti ir vertinti planuotus ir neplanuotus pokyčius, planuoti ir projektuotis savo karjerą, t. y. sudaryti karjeros kūrimo prielaidas. Tada išryškejja ị studentus sutelktų studijų nauda asmeniui ir visuomenei (t. y. mikroekonomikos ir makroekonomikos lygiais) (Čiburienè, Guščinskienė, 2017, p. 145):

- skatinamas šalies gyventojų mokymosi visą gyvenimą poreikis, lemiantis darbuotojų išlikimą vidutinės kvalifikacijos darbo jëgos rinkoje ir (arba) perējimą i aukštos kvalifikacijos darbo jëgos rinką, darant karjerą. Tokiu būdu žinios, praktika ir mokslas, plačiai taikant MTEP, lemiančią pažangios technologijos, tausojančios aplinką, diegimą, užtikrina darnų vystymąsi igyvendinant ekonominius, socialinius, kultūrinius ir aplinkosaugos tikslus;

- didinama studentų motyvacija ir jų aktyvumas, sudaromos karjeros kūrimo prielaidos, taip gerinama studijų kokybė, keliamas aukštojo mokslo prestižas ir aukštųjų mokyklų dèstytojai skatinami tobulèti;

- visuomenè gauna darbo jègą, pasirengusią priimti nestandartinius sprendimus, todèl didejja ūkinių veiklų konkurencingumas, auga pajamos, kuriama pridètinè vertè ir sudaromos sąlygos darniam ekonomikos vystymuisi.

\section{Karjeros samprata ir jos kūrimas aukštojoje mokykloje}

Aukštojo mokslo ịstaigos ugdo, rengia ir suteikia kvalifikaciją tam tikros studijų krypties studijas sèkmingai baigusiems absolventams, bet šio specialisto neparuošia karjerai, t. y. neparengia jam darbinès veiklos kelio, ị kuri ji gali nukreipti aukštujjų mokyklų karjeros centrai. Absolventai, integruodamiesi į darbo rinką, siekia karjeros, kurios sèkmè, kaip kompleksinio proceso rezultatas, priklauso nuo išorinių ir vidinių veiksnių. Išoriniai veiksniai susiję su dabartinio pasaulio sparčia kaita. Vyksta pokyčiai ekonomikoje, politikoje, socialiniame žmonių gyvenime, kultūroje ir kt., kinta įvairių žinių, gebèjimų, igūdžių poreikis dinamiškoje darbo rinkoje. Visa tai daro ịtaką XXI a. darbo rinkos dalyvių karjerai ir pačiai karjeros sampratai. Valickas, Chomentauskas, Dereškevičiūtè, Žukauskaitè ir Navickienė (2012, p. 13-27; 2014, p. 9-17) išskyrè pagrindines šių pokyčių priežastis: globalizaciją, informacinių technologijų revoliuciją, demografinius pokyčius ir kt. Tai paskatino reikalavimų darbuotojams ir organizacijoms kaitą. Būsimieji darbo rinkos dalyviai, dabartiniai studentai, darydami karjerą susidurs su: globalia konkurencija darbo rinkoje, organizacijų perèjimu nuo biurokratinių prie paprastesnių struktūrų, bendradarbiavimo svarbos išaugimo tendencijomis, vykdant įvairias užduotis, žemos kvalifikacijos darbuotojų poreikio mažèjimu, paslaugų sektoriaus plètra, nedarbo augimu, laikinų darbuotojų skaičiaus augimu, darbo jègos senėjimu, 
nuolatiniu sparčiu žinių senejimu ir jų atnaujinimo poreikiu, naujais reikalavimais darbuotojams, savarankiškai dirbančių asmenų skaičiaus augimu ir kt. Vidiniai veiksniai, veikiantys karjerą, susiję su asmens savybėmis, pvz., sukauptomis žiniomis, ịgytais ịgūdžiais, individualiomis pastangomis ieškant darbo ir pan.

Ivairių sričių mokslininkai: sociologai, psichologai, ekonomistai, edukologai ir kt., analizuoja karjeros fenomeną, išskirdami įvairius jo aspektus. Pvz., Laužackas (2005a) parenge profesinio rengimo metodologiją ir profesinio rengimo terminų aiškinamajj žodyną; Petkevičiūtė (2006), Korsakienè ir Smaliukienė (2014), Bohonos (2014) analizavo karjeros sampratą; Danilevičius (2008) gvildeno karjeros projektavimo ir planavimo edukologines ugdymo prielaidas; Tūtlys (2013) dèmesị sutelke ị karjeros projektavimo ir profesinio rengimo sąveiką; Pukelis ir Navickienè (2006), Pukelis (2012) tyrinėjo karjeros projektavimą, o Rudžinskienė ir Paulauskaitė (2012) - karjeros konsultantu problemas; Lamanauskas ir Augienè (2015a ir 2015b), Navickienè ir Tendzegolskienè (2012) bei Navickienė (2011) analizavo karjeros konsultavimo kvalifikacijos parametrus, o Pukelis ir Navickiené (2011) - karjeros konsultantų problemas; Urbonienè (2015) tyre studijų programos pasirinkimą kaip sèkmingos karjeros prielaidą; Valickas, Chomentauskas, Dereškevičiūtė, Žukauskaite ir Navickienė parenge karjeros valdymo vadovus studentams (2012; 2015), Pukelis ir Johannes (2014) gilinosi i paslaugų teikèjų akademinio rengimo modelio projektavimą Europoje; De Urraza ir Liesionienè (2013) apžvelgé besimokančiujų aukštojo mokslo ịstaigose karjeros projektavimo paslaugų poreikius ir jų teikimo galimybes; Baruch $(2004,2006)$ aptare karjeros plètrą ir transformacijas; Rosinaitė (2008) nagrinejjo Lietuvos aukštųjų mokyklų studentų karjeros vystymo kompetenciją; Bagučanskyte, Rutkienè (2013) tyrè karjeros planavimo veiksnius aukštojoje mokykloje; De Vos ir Cambre (2016) karjerą vertino ne tik individo, bet ir organizacijos interesų požiūriu; Hall (1996), Chin, ir Rasdi (2014), Korsakienè ir Smaliukienè (2014), taip pat Valickas, Chomentauskas, Dereškevičiūte, Žukauskaitè ir Navickienè analizavo nepastovios (kintančios) ir beribės karjeros modelius $(2012 ; 2015)$ ir pan.

Mokslinèje literatūroje (Rosinaitè, 2008; Bagučanskytė, Rutkienè, 2013) karjera apibūdinama kaip vienas svarbiausių asmens gyvenimo prioritetų, galintis tenkinti fiziologinius, socialinius, saugumo, materialinius, socialinio palankumo, saviraiškos poreikius ir kintantis nuosekliai ir sistemingai arba chaotiškai ir atsitiktinai.

Anot Lamanausko ir Augienės (2015a, p. 9), galimos dvi pagrindinès karjeros sampratos kryptys, susijusios su:

1) konkrečia profesine veikla, t. y. judama profesinèje arba organizacinėje erdvèje;

2) judèjimu nuo vieno asmens tapatumo link kito, t. y. tapatumai ir jų pokyčiai dažniausiai susiję su darbo, profesiniais ir organizaciniais vaidmenimis. Karjera gali būti suprantama kaip tam tikra individo tapatumo dinamika.

Mokslinèje literatūroje dažniausiai „karjeros“ sąvoka vartojama keliomis 
reikšmėmis (Petkevičiūtè, 2006):

1) karjera kaip pasiekimai (taip ji suvokiama daugiausia darbo aplinkoje);

2) karjera kaip profesija (ji gali būti daugiau ar mažiau prestižinė);

3) karjera kaip nuosekli nuolatinio darbo tąsa: kiekvienas dirbantis žmogus turi savo darbo istoriją, karjerą;

1) karjera kaip viso gyvenimo įvairių vaidmenų patirčių seka.

Pasak Aleliūnaitės ir Lapinsko (2014, p. 25-26), šiandien karjera neretai suprantama kaip:

1) aukštos pareigos organizacijoje. Žmogaus kilimas karjeros laiptais labiausiai priklauso nuo pačios organizacijos personalo politikos, paprastai tai vyksta tolygiai ir trunka visą gyvenimą;

2) profesiné veikla. Baigęs mokyklą asmuo pasirenka profesiją ir visą gyvenimą plètoja profesinę karjerą;

3) visa gyvenima trunkantis mokymosi ir darbo kelias. Šiuo atveju karjera tai visą gyvenimą trunkantis karjeros sprendimų prièmimo ir jų igyvendinimo procesas, kur kiekvienas pasirinkimas veda prie naujos karjeros situacijos ir nauju galimų karjeros alternatyvų. Nė vienas pasirinkimas negali užtikrinti karjeros visam gyvenimui. Labai svarbi darbo ir mokymosi veiklų sąsaja, arba sinergija. Siekiant būti konkurencingam darbo rinkoje, būtina turèti tam tikrų kompetencijų, kurios igyjamos mokantis, atnaujinant žinias.

Anot Valicko ir kt., karjera - tai visą gyvenimą trunkanti asmens darbo ir mokymosi patirčiu seka. Jie, aptardami karjeros sąvoką, atkreipia demesị i keletą esminių dalykų (Valickas ir kt., 2014, p. 259; Valickas ir kt., 2015, p. 27):

- vartojant sąvoką „karjera“, nurodoma ị asmens judejimą laike ir socialinèje erdvèje (pvz., judèjimas profesinèje ir organizacinèje erdvėse, perèjimas $i \mathfrak{i}$ to paties lygmens, bet skirtingo turinio ir funkcijų darbą (horizontali karjera);

- judejjimas socialinèje erdvèje yra lyginamas su iš anksto žinomu atskaitos tašku, lokalizuojamu socialinejje struktūroje ar santykių tinkle (objektyvi karjera);

- karjera gali būti suprantama ir kaip judejimas nuo vieno asmens tapatumo link kito (subjektyvi karjera).

Šiais atvejais ịvardijami darbo laimejjimai, einamos pareigos, igytos kvalifikacijos, išsiugdytos kompetencijos ir pan. Tačiau XXI a. vyksta spartūs pokyčiai, dèl kurių kinta ir reikalavimai kvalifikacijai: vienos profesijos praranda savo svarbą, kitos - ją igyja ir t. t. Tam nemažą ịtaką daro socialiné, ekonominé, politinè ir kita mus supanti aplinka.

Mokslininkų darbuose pristatomi ịvairūs aktualūs XXI a. karjeros modeliai, pvz., nepastovios, t. y. kintančios (,proteininès“), beribės, naujosios ir kt. karjeros variantai.

$\mathrm{XX}$ a. pab. atsirado nepastovios (kintančios) karjeros modelis (vadinamoji proteinine karjera). Šio modelio pradininkas Hallas (Hall, 1976, 2002 cit. iš Valickas ir kt., 2012, p. 31) šiuolaikinę karjerą vadina „proteinine“, terminą kildindamas iš graikų dievo Prometejjo, kuris panoreję̨s galëjo keisti savo būvị. Taigi šiandieninis 
darbo rinkos dalyvis, pagal aptariamaji modelį, turi taikytis prie kintančių išorinių reikalavimų ir, atsižvelgdamas ị savo poreikius, atrasti sau naujas sritis, koreguoti ir keisti karjeros krypti. Vadinasi, nepastovios (kintančios) karjeros modelio šalininkai yra įsitikinę, kad karjera yra lanksti ir mobili, o jos tikslus formuluoja pats individas (Hall, Mirvis, 1995 cit. iš Gruževskis ir kt., 2014, p. 45). Šis modelis akcentuoja asmens laisvę ir augimą, apibrèžia karjeros sẻkmę per psichologinius veiksnius, tokius kaip pasitenkinimas darbu, savęs aktualizavimas, asmeniniai pasiekimai ir kt., taip pat atkreipia dėmesị ị vertybes ir savireguliaciją (Chin ir Rasdi, 2014, p. 203). Tokios karjeros kelyje individas būna atviras naujoms galimybėms, kuriomis norint pasinaudoti reikia žinių, būtina mokytis naujų dalykų, atitinkančiu nūdienos dinamiškos aplinkos, organizacijos ir paties individo pokyčius. Pagal ši modelį, anot Gruževskio, Maslauskaitès, Korsakienès, Novagrockienès, Smaliukienès ir Šakočiaus (2014, p.46), kintančioje aplinkoje individai turi gebėti adaptuotis, mokytis iš savo pačių patyrimo ir patys ugdytis naujas kompetencijas, o tai yra glaudžiai susiję su kompetencijomis, kurios ugdomos aukštojoje mokykloje ị studentą sutelktų studijų laikotarpiu.

Arthur'as ir Rosseau pasiūlè beribès karjeros terminą kaip alternatyvą organizacinei karjerai, t. y. karjerai, kuri plètojama vienoje organizacijoje (Korsakiené, Smaliukienè, 2014, p. 87; Valickas ir kt., 2015, p. 31). Šiai karjerai būdinga (Valickas ir kt., 2015, p. 31) dažniau ,judèti“ per organizacijų ir profesijų ribas (darbuotojai dirba keliose organizacijose, dažnai keičia darbus ir (ar) profesijas ir kt.), lankstesni darbo santykiai (pvz., nuotolinis darbas, projektinis darbas ir t. t.) ir t. t.

$\mathrm{XX}$ a. paskutiniame dešimtmetyje pradèta rašyti apie naujaja karjera (Arnold ir Jackson, 1997 cit. iš Valickas ir kt., 2012, p. 33-34), kurios esmé - vertikalios karjeros galimybių sumažèjimas didelèse organizacijose, didesnès karjeros galimybès mažose organizacijose, dažnesni karjeros pokyčiai, poreikis mokytis visą gyvenimą, karjeros valdymo poreikis ir kt.

De Vos ir Cambre (2016) pabrèžia asmens vaidmenį karjeroje, tačiau dẻl ekonominiu procesų neapibrèžtumo akcentuoja karjeros valdymą ne biurokratiniu ar formaliu, bet organizacijos lygiu, kurị apibūdina keturiais aspektais:

- paramos karjerai ir jos vystymo praktikai;

- išskirtinių sandorių organizacijoje;

- individualios atsakomybès už karjerą;

- vidinio sutarimo (konsensuso) organizacijoje karjeros vystymo klausimu.

Tam, kad prisitaikytų prie naujų karjeros galimybių ir iššūkių, susijusių su tomis galimybėmis, studentas pirmiausia turi pažinti save. Todèl neatsitiktinai individo savęs pažinimas, jo vertybès ir vertybinès orientacijos, nusiteikimas, aktyvus siekis ir veikla karjeros plètros linkme vaidina bene didžiausią vaidmeni jo karjeros kelyje XXI a. aukštojoje mokykloje ị studentą sutelktų studijų metu, taip pat neformalaus ugdymo procese, siekiama paskatinti jaunimą pažinti save per, anot Lamanausko ir Augienès (2015b, p. 107), savęs pažinimo konstruktus:

- asmens turimus įsitikinimus apie karjerą ir jos siekimo principus; 
- suvokiamas karjeros kliūtis;

- asmens karjeros aspiracijas, atspindinčias tikslus ir ketinimus, kurie turi itakos renkantis karjeros kryptị ir tikslą;

- asmens karjeros lūkesčius, įžvalgas, kokių rezultatų gali tikètis atlikęs vienokius ar kitokius karjeros valdymo veiksmus;

- asmens karjeros brandą;

- asmens karjeros adaptyvumą;

- karjeros svarbą realizuojant savęs vertinimo lygi;

- gyvenimo ir darbo vertybes;

- individualią vertybių sistemą.

Šiame straipsnyje karjeros kūrimas apibūdinamas kaip karjeros planavimas ir projektavimas. Karjeros planavimas suprantamas kaip „nuoseklus asmens pažintinès ir profesinès veiklos sprendimų išdèstymas laike siekiant profesinio tobulëjimo tikslų bei numatant būtinus išteklius ir aplinkybes“ (Laužackas, 2005b, p. 17), o karjeros projektavimas - kaip nuolatinès žmogaus pastangos įžvelgti darbo rinkos kaitos tendencijas ir prognozuojamų pokyčių kontekste tirti, planuoti ir ịgyvendinti savo profesinès veiklos tobulinimo procesus, siekiant išlikti nuolat kintančioje darbo rinkoje ir ịprasminti savo gyvenimą (Pukelis, 2003).

\section{Karjeros kūrimo aukštosiose mokyklose praktika}

Šiandieninès aukštosios mokyklos aktyviai ịsitraukia ị studentų karjeros kūrimo procesus per karjeros konsultavimą, kaip karjeros planavimo sudedamają dalị. Daugelis Lietuvos aukštųų mokyklų turi savo karjeros centrus. 10 universitetų ir 16 kolegijų savo karjeros centrus yra sujungusios į sistemą Karjera.lt, kurios tikslas - teikti asmeninès karjeros valdymui reikalingą informaciją, irankius ir paslaugas, kurie pagerintų jaunų žmonių įsidarbinimo galimybes ir pasitenkinimo savo karjera lygị. Studentams ir absolventams sistema leidžia sėkmingai siekti profesinių tikslų, susirandant norimą praktikos ar darbo vietą (pvz., specialybę ir vietą Lietuvoje ar užsienyje), darbdaviams - atrasti perspektyvių ir kompetentingų darbuotojų, o plačiajai visuomenei - susipažinti su absolventų karjeros situacija darbo rinkoje (LSMU. Karjeros..., 2018). Šia sistema gali naudotis ị projektą ịsitraukusių Lietuvos aukštujų mokyklų studentai studijų laikotarpiu ir 5 m. jas baigę. Karjeros konsultantai turètų išmokyti studentus projektuoti savo karjerą.

Kiekvienos aukštosios mokyklos karjeros centras siūlo savo paslaugas studentams karjeros planavimo ir projektavimo klausimais. Pvz., Mykolo Romerio universiteto (toliau - MRU) centras studentams siūlo:

- konsultuotis karjeros ir akademiniais klausimais, teikia informaciją apie galimas praktikos ir darbo vietas bei karjeros valdymo informacinę sistemą, taip pat pasiūlymus universiteto veiklai tobulinti (MRU. Konsultavimas karjeros..., 2018), kurti ir plètoti asmeninès karjeros planus; 
- ugdytis karjeros valdymui reikalingas kompetencijas;

- ịvertinti karjerai svarbius asmenybės dalykus: savo interesus, vertybes, gabumus ir kt.;

- savarankiškai arba padedant konsultantui rasti karjeros problemų ar sunkumų sprendimus;

- rasti praktikos ir darbo vietas;

- ívertinti savo galimybes darbo rinkoje;

- parengti informatyvų ir darbdavio demesị atkreipiantị gyvenimo aprašymą;

- susikurti efektyvų darbo paieškos planą, susipažinti su įvairiais darbo paieškos būdais ir šaltiniais;

- pasirengti darbo pokalbiui (pvz., pasimokyti tinkamai save pristatyti per imitacinius pokalbius).

Vilniaus universiteto (toliau - VU) karjeros kompetencijų ugdymą vykdo Studentų paslaugų ir karjeros skyrius. Jis išskiria penkis šios veiklos etapus (VU. Karjeros paslaugos, 2018):

1) Savęs pažinimas. Testais ir individualių karjeros konsultacijų metu studentas įsivertina savo vertybes, interesus, kompetencijas, silpnąsias ir stipriąsias savybes, kurios yra svarbios renkantis savo karjeros kelią.

2) Savo karjeros galimybiu pažinimas. Studentas susipažįsta, kokios yra jo karjeros perspektyvos pasirinktoje srityje, kokios kompetencijos reikalingos, norint dirbti šioje srityje, kaip šių kompetencijų galima igyti studijuojant. Tai atliekama teikiant individualias konsultacijas ir organizuojant mokymus.

3) Studijoms svarbiu kompetenciju ugdymas. Studentai turi galimybę igyti igūdžių, padedančių mokytis efektyviau: streso valdymo, laiko planavimo, efektyvaus mokymosi, viešo kalbejjimo. Šie mokymai VU studentams yra nemokami.

4) Karjeros plano sudarymas. Planas sudaromas atsižvelgiant ị studento (absolvento) vertybes, turimas ir tobulinamas kompetencijas, pasirinktą karjeros kelią. Su karjeros konsultanto pagalba ir naudodamas elektronines priemones, studentas gali parengti savo karjeros planą ir aptarti jị kartu su specialistais. Karjeros planas - tai gairès, padedančios pasiekti užsibrèžtus karjeros tikslus.

5) Pagalba igyvendinant karjeros planą. Kiekvienam studentui (absolventui) padedama pasiruošti sẻkmingam darbo pokalbiui: parašyti patrauklu gyvenimo aprašymą, motyvacinį laišką, prisistatyti darbdaviui; atsakoma ị klausimus, kaip reikètu atrodyti ir ką sakyti, organizuojami bandomieji (imitaciniai) darbo pokalbiai. Studentai (absolventai), norėdami gauti nuotolinę konsultaciją dèl gyvenimo aprašymo ar motyvacinio laiško, gali siųsti savo gyvenimo aprašymą ar motyvacini laišką el. paštu i karjeros centrą ir per tris darbo dienas gauti patarimų dèl jų tobulinimo.

Kauno technologijos universiteto (toliau - KTU) karjeros centras kviečia studentus konsultuotis šiomis temomis:

- gyvenimo aprašymas ir motyvacinis laiškas (tiesiogiai arba internetu); 
- praktikos (darbo) paieškos strategija;

- pasirengimas pokalbiui dèl darbo;

- darbo pokalbio imitacija (simuliacija);

- silpnybių ir stiprybių nustatymas, karjeros planavimas ir kt.

KTU konsultantai taip pat teikia praktinius patarimus, kaip susikurti patrauklius darbo paieškos dokumentus, ir siūlo atsisiųsti įvairių dokumentų šablonus (pvz., gyvenimo aprašymo, motyvacinio laiško ir kt.). Universitete $2018 \mathrm{~m}$. prasidèjo sumaniujjų praktikų projekto „Patirties partneriai LT“ trijų dienų mokymų ciklas, skirtas sumaniujų praktikų metodologijai pristatyti. Studentai, suburti ị tarpdisciplinines komandas, galès praktiškai išbandyti tarptautines metodikas Design thinking, Business model canvas, Lego serious play. Mokymai skirti studentų nauju idejjų generavimo įgūdžiams, gebèjimams rinkti, analizuoti, kritiškai vertinti informaciją, išgryninti situaciją ir dirbti komandoje ugdyti. Mokymuose igytos žinios bus taikomos sumaniujų praktikų metu, sprendžiant verslo įmonių pateiktus klausimus ir problemas. Universitetas teikia praktikos ir savanorystès pasiūlymus, turi parengęs ịvairių seminarų ciklų kalendorių (pvz., viešojo kalbèjimo, improvizacijų klubo ir kt.).

Užsienio aukštosiose mokyklose taip pat vyksta karjeros kūrimo procesai. Pvz., JAV aukštujų mokyklų karjeros kūrimo procesas atitinka jos loginę seką, t. y. jos siekiama žingsnis po žingsnio, palaipsniui ịgyjant vis daugiau žinių apie karjerą, pasiruošimą jai ir kt. (1 lentelè)

1 lentelè

\section{apibūdinimas \\ Kalifornijos liuteronų universiteto karjeros kūrimo žingsniai ir jų}

\begin{tabular}{|l|l|}
\hline \multicolumn{1}{|c|}{ Žingsnis } & \multicolumn{1}{c|}{ Apibūdinimas } \\
\hline 1. Karjeros galimybių ištyrimas & $\begin{array}{l}\text { Pirmas žingsnis skirtas darbo rinkoje siūlomų pozicijų analizei } \\
\text { (karjeros tyrimams) ir joms užimti keliamiems reikalavimams, } \\
\text { t. y. ǐvardijamos būtinos žinios, gebejjimai ir igūdžiai bei } \\
\text { asmeninès savybès, kurių reikia sėkmingai profesinei veiklai } \\
\text { ir karjerai. }\end{array}$ \\
\hline 2. Lauko tyrimų atlikimas & $\begin{array}{l}\text { Antras žingsnis svarbus renkantis vieną iš kelių galimų veiklos } \\
\text { sričiu. Geriausias būdas ištirti karjeros galimybes - susipažinti } \\
\text { su žmonėmis, dirbančiais toje srityje. Tai - pirmasis etapas, } \\
\text { kuriant profesionalų tinklą. Karjeros centrai, noredami padèti } \\
\text { studentams šiame etape, siūlo savo paslaugas. }\end{array}$ \\
\hline
\end{tabular}




\begin{tabular}{|c|c|}
\hline 3. Savo darbo tikslo nusistatymas & $\begin{array}{l}\text { Trečias žingsnis žengiamas atlikus savo karjeros ir lauko tyri- } \\
\text { mus ir išnagrinėjus savo galimybes - priimamas sprendimas } \\
\text { ir išsikeliama keletas tikslų. Šio sprendimo esmè - (darbo } \\
\text { paieškos tikslas, t. y. konkreti pramonès (veiklos) sritis, } \\
\text { pasirinkta pozicija ir (arba) geografinė vietovė. Darbo pa- } \\
\text { sirinkimo tikslas gali kisti priklausomai nuo igytos patirties ir } \\
\text { sukauptų žinių. }\end{array}$ \\
\hline $\begin{array}{l}\text { 4. Savo gyvenimo aprašymo } \\
\text { parengimas }\end{array}$ & $\begin{array}{l}\text { Ketvirtas žingsnis apima: ịvairių kursų, seminaru ir mokymų } \\
\text { lankymą; knygų, žurnalų ir laikraščių, susijusių su profe- } \\
\text { sine veikla, skaitymą; dalyvavimą profesinėse asociacijose, } \\
\text { klubuose, stovyklose ir kt. }\end{array}$ \\
\hline 5. Pasiruošimas darbo paieškai & $\begin{array}{l}\text { Žengiant penktą žingsnị rekomenduojama domètis ịmonèmis } \\
\text { ir organizacijomis, kuriose norima dirbti, išsiaiškinti, ar } \\
\text { yra tarp draugų, šeimos narių, pažistamų ar karjeros centro } \\
\text { atstovų, kurie turi kontaktų su dominančiomis įmonemis } \\
\text { ir organizacijomis, iš kurių būtų galima gauti naujausios } \\
\text { reikšmingos informacijos. Iš anksto verta pasidomèti apklausų, } \\
\text { atliktų apie dominančias įmones, rezultatais, jose mokamo } \\
\text { darbo užmokesčio dydžiu ir kt. Tam tinka susitikimai su darb- } \\
\text { daviais, kuriuos organizuoja karjeros centras. }\end{array}$ \\
\hline
\end{tabular}

Šaltiniai: sudaryta pagal Five Steps to..., 2018

Kalifornijos liuteronų universiteto karjeros kūrimo žingsniai rodo individo išsimokslinimo (žinių, gebejjimų, igūdžiu ryšị su jo asmeninèmis savybėmis ir jų tarpusavio sąveiką. Šis individo išsimokslinimo ir asmeninių savybių ryšys atskleidžia vidinius veiksnius, lemiančius karjeros sẻkmę. Praktika rodo, kad karjeros centrų veikla, padedanti studentams karjeros, kaip kompleksinio proceso, plètros klausimais, yra reikšminga grandis, sujungianti vidinius ir išorinius (darbo rinka, ūkio veikla, organizacija, regionas, šalis ir pan.) karjeros kūrimo veiksnius.

\section{Išvados}

XXI a. pr. darbo rinkoje ypatingas dėmesys skiriamas darbuotojų igytoms kompetencijoms, pvz., profesinei, socialinei, bendrakultūinei, efektyvios veiklos, komunikacinei, informacijos ir pokyčių valdymo, ugdomoms ị studentą sutelktų studijų laikotarpiu. Šios studijos naudingos asmeniui ir visuomenei, t. y. mikroekonomikos ir makroekonomikos lygiais: skatina žmones mokytis visą gyvenimą, didina studentų motyvaciją ir aktyvumą, gerina studijų kokybę, kelia aukštojo mokslo prestižą ir t. t.

Karjera - tai visą gyvenimą trunkanti asmens darbo ir mokymosi patirčių seka, o karjeros kūrimas suprantamas kaip jos planavimas ir projektavimas. Karjeros kūrimui įtaką daro išoriniai veiksniai, susiję su dabartinio pasaulio sparčia kaita, t. y. ekonomikos, politikos, socialinio žmonių gyvenimo, kultūros ir kt. pokyčiais, taip pat vidiniai veiksniai, susiję su asmens savybėmis, pvz., sukauptomis žiniomis, igytais ịgūdžiais, asmens pastangomis ieškant darbo ir pan.

Šiandieninejje visuomeneje karjera kuriama sąveikaujant individui, organizacijai ir visuomenei, t. y. karjera planuojama ir projektuojama derinant for- 
malųji ir neformalujj ugdymą, plètojant socialinius tinklus ir kt. Asmens igytos teorinès žinios susiejamos su praktiniais įgūdžiais ir derinamos su rinkos poreikiais, ugdomas gebejimas bendrauti ir spręsti iškilusias problemas, priimti, perduoti ir interpretuoti informaciją, kas sukuria tolesnès sėkmingos karjeros prielaidas.

Daugelis Lietuvos ir užsienio aukštųjų mokyklų turi savo karjeros centrus, kurie studentams ir absolventams padeda sëkmingai siekti profesinių tikslų, susirasti norimą praktikos ar darbo vietą, darbdaviams - atrasti perspektyvių ir kompetentingų darbuotojų, o visuomenei - susipažinti su absolventų karjeros situacija darbo rinkoje.

\section{Literatūra}

1. Aleliūnaitè, R., Lapinskas. E. (2014). Karjeros konsultavimas. Vilnius: [Žiūrèta 2017-03-21.] Prieiga per internetą: https://karjera.lt/ documents/10180/1128126/Karjeros+konsultavimas + .pdf/87fa07f4-039e-45bf$8 \mathrm{c} 29-5 \mathrm{dd} 0 \mathrm{~b} 40 \mathrm{bf} 2 \mathrm{aa}$

2. Bagučanskytè, M., Rutkienè, A. (2013). Bakalauro studijų studentų karjeros planavimo veiksniai: VDU edukologijos katedros atvejis. Aktualios ugdymo problemos akademinio jaunimo tyrimuose: straipsniu rinkinys, p. 75-78.

3. Baruch, Y. (2006). Career development in organisations and beyond: balancing traditional and contemporary viewpoints. Human Resource Management Review, No.16, p 125-138. http://dx.doi.org/10.1016/j.hrmr.2006.03.002

4. Baruch, Y. (2004). Transforming careers: from linear to multi directional career paths. Organisational and individual perspectives. Career Development International, No.9 (1), p. 58-73. http://dx.doi.org/10.1108/13620430410518147

5. Bohonos, J. (2014). Understanding career context as a key to best serving adult students. Adult Learning, No. 25 (1), p. 28-30.

6. Chin, W., S., Rasdi, R., M. (2014). Protean Career Development: Exploring the Individuals, Organizational and Job-related Factors. Asian Social Science, Vol. 10, No. 21, p. 203-215.

7. Cox, J. (2011). Kas yra ir kas nèra i studenta orientuotas mokymas(is)? [Žiūrèta 2017-01-21.] Prieiga per internetą: http://www.ects.cr.vu.lt/Files/File/cox.pdf

8. Čiburiené, J., Guščinskiené, J. (2017) Studijų orientavimas ị studentą darnaus vystymosi kontekste. Šiuolaikinès visuomenès ugdymo veiksniai, p. 139-149.

9. Danilevičius, E. (2008). Karjeros projektavimo ir karjeros planavimo ugdymo edukologinès prielaidos. Vilnius: Pedagoginio universiteto leidykla, Nr. 92, p. $110-115$.

10. De Urraza, M., J., Liesionienè, O. (2013)17-27 metų besimokančiujų aukštojo mokslo ịstaigose karjeros projektavimo paslaugu poreikis ir jų teikimo galimybès Lietuvoje ir Argentinoje. Aktualios ugdymo problemos akademinio jaunimo tyrimuose: straipsniu rinkinys, p. 52- 61.

11. De Vos, A., Cambre, B. (2016). Career management in high-performing 
organization: a set-theoretic approach. Human resource management, p. 1-18.

12. Five Steps to Career Planning. [Žiūrèta 2018-05-21.] Prieiga per internetą: http:/cravencc.edu/students/career-transfer-services/five-steps-to-career-planning/

13. Korsakienè, R., Smaliukienè, R. (2014). Šiuolaikinè karjera individo požiūriu: karjeros modeliai, jų sąsajos ir reikšmè. Verslas: Teorija ir praktika, Nr. 15 (1), p. 84-92.

14. KTU „WANTed“ karjeros dienos. (2018) Kauno technologijos universitetas. [Žiūrèta 2018-05-21.] Prieiga per internetą: https://studentams.ktu.edu/paslaugos/wanted/

15. Lamanauskas, V., Augienè, D. (2015a). Universiteto studentu karjeros supratimas, darbo vertybių, kompetencijų ir studijų i̇takos profesinei karjerai vertinimas. Švietimas: Politika, vadyba, kokybe, 2015, Vol. 7, No. 1, p. 8-26.

16. Lamanauskas, V., Augienè, D. (2015b). Universiteto studentų profesinė karjera: supratimo struktūra. Švietimas: Politika, vadyba, kokybè, Vol. 7, No. 3, p. 106-117.

17. Laužackas, R. (2005a). Profesinio rengimo metodologija. Monografija. Kaunas: Vytauto Didžiojo universitetas.

18. Laužackas, R. (2005b). Profesinio rengimo terminu aiškinamasis žodynas. Kaunas: Vytauto Didžiojo universitetas.

19. Lietuvos sveikatos mokslų universitetas. Karjeros planavimas (2018). [Žiūrèta 2018-03-21.] Prieiga per internetą: http://www.lsmuni.lt/lt/struktura/akademiniai-padaliniai/karjeros-centras/karjeros-planavimas/

20. Mykolo Romerio universitetas. Konsultavimas karjeros klausimais (2018). [Žiūrèta 2018-03-21.] Prieiga per internetą: http://www.mruni.eu/lt/universitetas/struktura/karjeros_centras/konsultavimas/konsultavimas-karjeros-klausimais-l

21. Navickienè, L. (2012). Karjeros konsultanto kvalifikacijos parametrai. Karjeros projektavimas: tyrimai ir konsultavimas, Nr. 1, p. 91-113.

22. Navickienè, L. Tendzegolskienè I. (2011). Pagrindiniai karjeros konsultantų rengimo parametrai. Profesinis rengimas: tyrimai ir realijos, Nr. 21, p. 10-29.

23. Gruževskis, B., Maslauskaite, A., Korsakienè, R., Novagrockienė, J., Smaliukienè, R., Šakočius, A. (2014). Pareigūnu ir karių antroji karjera. Monografija. Vilnius: LKA.

24. Peilakauskaite, K., Varanauskas, A. (2011). Studiju programu atnaujinimas: studentu vaidmuo diegiant ir tobulinant kompetencijomis grista ir $\underline{i}$ studentus orientuota studiju sistema. Vilnius: Vilniaus universitetas.

25. Petkevičiūtè, N. (2006). Karjeros valdymas: asmenine (individualioji) perspektyva. Mokomoji knyga. Kaunas: Vytauto Didžiojo universiteto leidykla.

26. Powell, M. (2014). 5 ways to make your classroom student-centered. [Žiūrèta 2017-02-13.] Prieiga per internetą: http://www.edweek.org/tm/ articles/2013/12/24/ctq_powell_strengths.html

27. Pukelis, K. (2003). Karjeros projektavimo gebèjimai žinių visuomenè- 
je: nauji iššūkiai profesiniam konsultavimui ir karjeros planavimui. Profesinis rengimas: tyrimai ir realijos. Kaunas: Vytauto Didžiojo universiteto leidykla, Nr. 6, p. 66-75.

28. Pukelis, K. (2012). Karjeros projektavimas: kodėl ir kas? Karjeros projektavimas: tyrimai ir konsultavimas, Nr. 1, p. 12-45.

29. Pukelis, K., Navickienè, L. (2011). Karjeros konsultantų profesijos problema. Profesinis rengimas: tyrimai ir realijos, Nr. 20, p. 116-133.

30. Rosinaitè, V. (2008). Lietuvos aukštųjų mokyklų studentų career development kompetencijos: subjektyvus jų įsisavinimo lygio ir ugdymo poreikio įvertinimas. Filosofija. Sociologija. Vilnius: Lietuvos mokslų akademijos leidykla, t. 19, Nr. 4, p. 62-71.

31. Rudžinskienè, R., Paulauskaitė, L. (2012). Karjeros projektavimo gebejjimų ugdymas. Studijos šiuolaikineje visuomeneje, Nr. 3 (1), p. 203-213.

32. Sajienè, L., Tamulienè, R. (2012). Studijų turinio kaita ị studentą orientuotu studijų paradigmoje: teorinis aspektas. Profesinis rengimas: tyrimai ir realijos, Nr. 23, p. 96-107.

33. Tūtlys, V. (2013). Karjeros projektavimo ir profesinio rengimo sąveika Lietuvoje: galimybių spąstų problemos sprendimas. Karjeros projektavimas: tyrimai ir konsultavimas, Nr. 2, p. 29-53.

34. Urbonienè, L. (2015). Studijų programos pasirinkimas kaip sėkmingos karjeros prielaida. Profesinés studijos: teorija ir praktika, Nr. 15, p. 143-146.

35. Valickas, A., Chomentauskas, G., Dereškevičiūtè, E., Žukauskaite, I., Navickienè, L. (2015). Asmeninès karjeros valdymas. Studentui. Vilnius: UAB LODVILA.

36. Valickas, A., Chomentauskas, G., Dereškevičiūtè, E., Žukauskaitè, I., Navickienè, L. (2014). Asmeninès karjeros valdymas. Metodiné priemoné dèstytojui. Šiauliai : AB spaustuvė Titnagas.

37. Valickas, A., Chomentauskas, G., Dereškevičiūtė, E., Žukauskaitè, I., Navickienè, L. (2012). Karjeros valdymo vadovas. Studentui. Vilnius: UAB LODVILA.

38. Vilniaus universitetas. Karjeros paslaugos (2018). [Žiūrèta 2018-03-21.] Prieiga per internetą: https://www.vu.lt/studijos/studentams/karjeros-paslaugos

39. Weimer,M.(2013).Leaner-centered teaching:fivekey changesto practice. 2 ed. [Žiūrèta 2017-03-03.] Prieiga per internetą: https://www.amazon.com/LearnerCentered-Teaching-Five-Changes-Practice/dp/1118119282\#reader_1118119282 


\title{
STUDENT-CENTERED STUDIES AS A PREREQUISITE FOR CAREER DEVELOPMENT
}

\author{
Assoc. Prof. Dr. Jūratė Guščinskienė \\ General Jonas Žemaitis Military Academy of Lithuania \\ Prof. Jadvyga Čiburienè \\ Kaunas University of Technology
}

\section{Summary}

The processes of globalization and economic integration are based on the creation of knowledge-based society and career. Career is defined as the change of person's work activities in a particular field and profession during time period. In today's society, career describes the success of an individual's activities and personal life.

The advancement of higher education is one of the key conditions for the society development. The relationship between higher education system and labour market is ensured through students' knowledge, abilities, competences, and skills. In the context of sustainable development, student-centred studies promote the development of different learner competences, such as transformational, instrumental, social and other skills. Teacher competences, such as complex thinking, prospect anticipation, implementation of changes, are developed as well.

The object of the research is student-centred studies.

The aim of the research is to analyze student-centred studies as a prerequisite for career development.

The objectives of the research are as follows: 1) to analyze student-centred studies; 2) to analyze the concept of career and its prerequisites for its development at a higher education institution.

The research methods used: the analysis of scientific literature and documents and interpretation.

Student-oriented studies at the institutions of higher education is an essential driver for enhancing the expertise of labour force and increasing the involvement of sufficiently and highly qualified employees in the labour market. This model of studies is beneficial to learners as well as to organizations and society.

The article describes the concept of career, its planning and designing processes and counselling and planning services provided by higher education institutions. The literature analysis showed that career development has become a lifelong process. Career counselling and planning services are important for educational system and labour market.

The article presents illustrative examples of career development in Lithuanian and foreign higher education institutions.

Keywords: student-centred studies, higher education, career, career planning and designing, career development. 


\section{AUTORIŲ LYDRAŠTIS}

Autoriaus vardas, pavardė: Jūratė Guščinskienè

Mokslo laipsnis ir vardas: socialinių mokslų daktarè, docentė

Darbo vieta ir pareigos: Generolo Jono Žemaičio Lietuvos karo akademijos Doktorantūros studijų vadovè, Vadybos katedros docentė

Autoriaus mokslinių interesų sritys: organizacijų sociologija, socialinė deviacija, organizacijų komunikacija, aukštojo mokslo problemos ir kt.

Telefonas ir el. pašto adresas: (8 5) 2103592, jurate.guscinskiene@mil.lt

Autoriaus vardas, pavardė: Jadvyga Čiburienè

Mokslo laipsnis ir vardas: socialinių mokslų daktarè, profesore

Darbo vieta ir pareigos: Kauno technologijos universiteto Ekonomikos ir vadybos fakulteto Ekonomikos katedros profesore

Autoriaus mokslinių interesų sritys: makroekonomika, ekonominis augimas, ekonominé politika, ekonomikos stabilizavimo politika, jaunimo problemos ir kt.

Telefonas ir el. pašto adresas: (37) 3005 76, jadvyga.ciburiene@ktu.lt

\section{AUTHORS' COVER LETTERS}

Author's name and surname: Jūratė Guščinskienė

Academic degree and name: Doctor of Social Sciences, Associate Professor

Work place and position: General Jonas Žemaitis Military Academy of Lithuania, Head of PhD Studies

Author's research interests: sociology of organizations, organizational communication, problems of higher education, social deviance

Telephone and e-mail address: +370 5210 3592; jurate.guscinskiene@mil.lt

Author's name and surname: Jadvyga Čiburienė

Academic degree and name: Doctor of Social Sciences, Professor

Work place and position: Kaunas University of Technology, School of Economics and Management, Department of Economics, Professor

Author's research interests: economic stabilization policy, macroeconomics, economic growth, economic policy, problems of higher education

Telephone and e-mail address: +370 3730 0576, jadvyga.ciburiene@ktu.lt 